\title{
X-Efficiency among Chinese Banks
}

\author{
Roger Frantz, Taylor Mackay \\ San Diego State University, San Diego, USA \\ Email: rfrantz@mail.sdsu.edu
}

Received 23 January 2015; accepted 3 March 2015; published 6 March 2015

Copyright (C) 2015 by authors and Scientific Research Publishing Inc.

This work is licensed under the Creative Commons Attribution International License (CC BY).

http://creativecommons.org/licenses/by/4.0/

cC) (i) Open Access

\begin{abstract}
X-efficiency is a non-allocative form of efficiency first introduced by Harvey Leibenstein in 1966. The degree of $X$-efficiency is measured by the deviation of a firm's costs of production from the technologically minimum costs of production. X-efficiency theory predicts that firms will produce closer to their cost function when they face pressure to do so. In this paper we review studies of $\mathrm{X}$-efficiency among Chinese banks. These studies include the effect of ownership form, for example, state-owned banks versus privately-owned banks, on costs of production. China's entrance into the WTO, the effect of a bank issuing an IPO and the effect of bank size are other topics of empirical studies reviewed in this paper. In addition some studies on Hong Kong banks before 1997 are included.
\end{abstract}

\section{Keywords}

X-Efficiency, China, Allocative Efficiency, Bank Size, Ownership Form, WTo

\section{Introduction}

In 1966, the year Leibenstein first wrote about X-Efficiency (XE) theory [1]: efficiency implied allocative efficiency, and rationality meant the complete rationality of "economic man".

Allocative efficiency means that Price (P) is equal to Marginal Cost (MC), and the marginal products per dollar spent on all inputs are equal with each other $(\mathrm{MPl} / \mathrm{Pl}=\mathrm{MPk} / \mathrm{Pk}=\cdots \mathrm{MPn} / \mathrm{Pn})$. If either or both of these did not hold, then allocative inefficiency existed. No one took issue with this form of inefficiency, which represented a market failure caused by market power of one or more firms. However, allocative efficiency theory neglects the possibility of intra-firm inefficiencies that firms are not cost minimizers. This internal inefficiency is what Leibenstein defined as X-Inefficiency (XIE). XE theory does not focus on prices and outputs, but on costs. More than a few economists took exception to the possibility of this type of inefficiency. If it exists then it calls into question whether people are rational or economic men. An economic man would minimize the firm's costs, but a "XIE man" does not. Since 1967 over 200 empirical studies on XE theory have been conducted. These studies have used data from all over the world and the empirical results are largely consistent with each other and with 
XE theory. The last "wave" of studies has been on banking. The results reported here are consistent with the results of studies in the banking industry from all over the world.

\section{Allocative and X-Efficiency}

Empirical estimates of the size of allocative inefficiency-price and output deviations from the socially rate of output (SORQ) where $\mathrm{P}=\mathrm{MC}$-reveal that for the entire US economy allocative inefficiency is less than one percent of the GDP. Some estimates have it between 0.001 and 0.0001 of GDP. For a \$16 trillion GDP this is equal to between $\$ 16,000,000,000$ and $\$ 1,600,000,000$. Each year Americans spend $\$ 18,000,000,000$ on specialty coffee, and $\$ 7,000,000,000$ on potato chips. Allocative inefficiency is, to use a line from the Godfather, "small potatoes". It is, for all intents and purposes, insignificant. Robert Mundell (1999), winner of the Nobel Prize in Economics thus lamented that if inefficiency is insignificant then so are economists (Mundell, 1962) [2]! Fortunately inefficiency is not limited to allocative inefficiency. X-inefficiency-internal inefficiency of the firm - costs higher than technologically necessary costs - has been estimated to be in the area of three percent of the GDP. For a $\$ 16$ trillion economy this is $\$ 480,000,000,000$. One reason X-inefficiency is larger than allocative inefficiency is because $\mathrm{X}$-inefficiency applies to every unit of output produced by a monopoly firm, whereas allocative inefficiency only applies to the change in output due to the higher price charged by the monopoly firm - the welfare triangle.

\section{Why Does X-Inefficiency Exist?}

Leibenstein presents several reasons for the X-istence of XIE. First, the human personality contains two parts, a superego and an id. The superego wants to work hard, improve themselves, do things correctly, find solutions to problems using rational decision making processes. The id wants to be free of effort. The id wants to be free of effort employing lazy decision rules and employs lazy decision rules, only moderate work effort, both of which raise costs above the technological necessary minimum. Second, managers are only rarely the owners, creating an "agency problem". Third, workers have discretion about levels of work effort. Additionally, numbers two and three above are compounded when firms have monopoly power giving employees an environment in which they can pursue their own interests rather than the firm's interests. Monopoly power thus triggers non-cost minimizing behavior. We may thus expect government regulation of firms, for example, public utilities, to trigger $\mathrm{X}$-inefficiency.

\section{China's Banking System}

China is a perfect example for testing XE theory. They had a communist government and a communist economy. Under Mao the profit motive, western technology and economic aid from the West were downplayed, even made illegal. Entrepreneurs were considered bourgeoise criminals. However, beginning in 1979 the Chinese Communist Party began to roll back many of Mao's programs and expressed the benefits of the profit motive, market prices, and entrepreneurs. How did these changes affect the efficiency of Chinese economic organizations, specifically banking? This paper will review studies of Chinese banks and XE.

Chinese banking reforms may be said to begin in 1979 (Fu \& Hefferman, 2009) [3] with the creation of a "two tier" banking system: the PBC, and four state owned banks. The latter consisted of the Bank of China (BOC), the Agricultural Bank of China (ABC), the China Construction Bank (CCB) and the Industrial and Commercial Bank of China (ICBC). PBC remained China's central bank, but commercial activities were the focus of the four state-owned banks. Beginning in 1985 the state owned banks had nation-wide branches and were accepting deposits and making loans. By 1986 they were engaged in universal banking. "Small and medium sized" commercial banks were introduced in 1985 in order to promote competition.

1993 saw the "Decision on Financial System Reform", during which time state banks were allowed to compete along-side other banking institutions, in an effort to introduce competition. The PBC was in charge of monetary policy, but the China Banking Regulatory Commission (BRC, 2003) took over the regulatory function formerly in the hands of the PBC. The BRC allows foreign institutions to own as much as $25 \%$ of a Chinese financial institution.

Three state-owned Policy Banks (PB) were created in 1994 to make loans formerly done by the SOCBs. In 1999 China created four Asset Management Companies (AMC), one for each of the Big Four state-owned 
commercial banks. Formed as a way to compensate the Big Four for their service to the nation, the AMCs were created to take over the Big Four's NPLs. In 1999 about 1.5 trillion RMB in NPLs were taken over, an amount equal to about $20 \%$ of China's GDP.

Eleven joint stock-owned banks were created in 2005. It is important that the primary stockholders of these "private enterprise" banks were the State-Owned Enterprises (SOEs). There were 111 city commercial banks owned by local public and private institutions, three rural commercial banks, and 35,544 rural credit coops. By 2004 there were about 204 foreign bank subsidiaries. In the Commercial Bank Law in 1995, Chapter I General Provisions, Article 1 states the desire for modern financial system, protecting the legal rights of banking participants, strengthening the internal structure and performance of commercial banks, while promoting the socialist market economy.

In 1998 the government ended credit quotas. Beginning in 1998 banks could adjust interest rates within a "modest" amount to take risk into account. Capital injections reduced Non-Performing Loans (NPLs) which helped several banks in their successful IPOs on Shanghai and Hong Kong Stock Exchanges. In October 2005 the China Construction Bank initiated an IPO, China's banking sector's first IPO. The IPO was listed on the Hong Kong stock exchange. This was the first time that Chinese stock was listed in an overseas stock exchange. The various reforms have had positive effects. For example, among the largest state-owned banks the NPL ratio which was about $30 \%$ in 1999 dropped to $10.5 \%$ in 2005 and then to $6.7 \%$ in 2007 , and $2.8 \%$ in 2008. Bank profits, measured as either ROA or ROE increased. From 2002 to 2006 ROE and ROA increased about three times, reaching levels of about $11 \%$ and $0.5 \%$, respectively. In 2001 China joined the WTO and had five years to open up their banking sector to international competition. Opening the economy to foreign interests was essential for China's membership in the WTO. Foreign banks were required to have unrestricted access to the Chinese financial sector. By 2007-2009 Chinese banks were the largest commercial banks in the world. The recession of 2007-2009 had intense effects on the world's financial sector. On the one hand, financial giants such as Citigroup, and the Royal Bank of Scotland saw their stock prices fall by more than $95 \%$. On the other hand, China's three large state-owned commercial banks became the world's three largest commercial banks.

Hong Kong was a Special Administrative Region of the People's Republic of China from 1898 until 1997. Hong Kong has maintained its status as one of the world's preeminent hubs of economic and financial activity. The laissez-faire attitudes toward banking and commercial activity among Hong Kong banks are well known. Hong Kong is home to the $5^{\text {th }}$ largest stock market in the world, and is home to more than 150 licensed banks. However, banks were also protected from competition, at least until the deregulation of interest rates in 1994. In addition, many medium-sized banks are privately owned and controlled by the founding family. These banks did not respond to market incentive as would a publically listed bank. Overall, economic policy changes in the years since the East Asian financial crisis, as well as the entrance into the World Trade organization by China (2001) and Hong Kong (1995), have been significant.

\section{X-Efficiency among Chinese Banks}

First, several articles about the effects of ownership form. Fu and Hefferman (2007) [4] studied four state-owned and ten joint-stock owned banks from 1985-2002, which were divided into two reform periods, 1979-1992 and 1993-2002. Average bank XE was between 0.4 and 0.6, implying that the average bank could have lowered its costs by between $40 \%$ and $60 \%$ for the same output rate. Pressured by the government, the state-owned banks gave significant loan volumes to state-owned firms losing money. The incentives for the managers of stateowned banks lacked a strong motive to keep the bank on the cost and/or production frontier. And customers who knew that the loans were guaranteed by the government lacked the strong incentive to repay the loans. The resulting non-performing loans reduce the XE of these banks.

Given the existence of asymmetric information, agency theory predicts that managers will act in their own interests rather than in the interests of the owner-principals. Fu and Hefferman state that this will be the case in both state-owned, and privately-owned firms. However, XE theory predicts that state-owned banks will suffer more from this problem. Fu and Hefferman state that agency problems may offset any positive effects of banking reforms. As predicted by XE theory, the privately-owned joint-stock banks were about $20 \%$ more X-efficient than the state-owned commercial banks.

Yao, Jiang, Feng, and Willenbockel (2007) [5] used data from 22 banks over the period 1995 to 2001. Average bank XE was approximately 0.65 . Privately-owned banks averaged $8 \%$ to $18 \%$ more X-efficient than state- 
owned banks. The range of individual bank XE was 0.91 to 49. For China's "Big 4" banks the range was 0.92 to 0.25 . The estimated average XE of state-owned banks is 0.6 and that of privately-owned joint-stock banks is 0.77. Banks subject to a hard budget constraint are predicted to be more XE. The authors measure a bank's subjection to a hard budget constraint with their equity/asset ratio. Being capitalized by the state creates a high equity/asset ratio. A high equity/asset ratio will, in turn reduce the willingness to take risks. Regression results show that a higher equity/asset ratio reduces $\mathrm{XE}$ as does state-ownership.

Jiang, Yao, and Zhang (2009) [6] estimated efficiency for all major commercial banks in China which control more than $85 \%$ of bank assets for the period 1995-2005. The average level of XE was about 0.7. Joint Stock Commercial Banks (JSCB) are overall the most X-efficient with an average level of $81 \%$. JSCBs are $9 \%$ more X-efficient than State-Owned Commercial Banks (SOCB) and used it to generate profit levels closer to the maximum possible. Banks which were shown to be more X-efficient had three important characteristics: they were privately-owned JSCB, they were listed on a stock exchange and hence subject to all the pressures which come from needing to raise funds in the private market, and they had a lower equity/asset ratio.

Fu and Hefferman (2009) [7] used two sub-periods, 1979-1992 (stage 1) and 1993-present (stage 2) to investigate XE among JSCBs, and SOCBs. JSCBs were about 7\% more X-efficient than are SOCBs. JSCBs also had higher rates of return on both their assets and their equity. The average level of XE was $26 \%$ lower in stage 2 than stage 1. XE among state-owned banks was $48 \%$ lower. Rapid growth of the banks led the SOCBs, especially the "Big 4" to grow beyond optimal size and into the area of diseconomies of scale. The resulting higher costs reduced X-efficiency, and profits. State banks contributed to the decline in X-efficiency in another way. They continued to be pressured to make loans to inefficient state-owned enterprises. JSCBs, whose directors/owners were SOCBs were also pressured to lend money to losing state-owned enterprises.

García-Herrero, Gavilá, and Santabárbara (2009) [8] investigated the causes of low profits among 87 Chinese banks accounting for more than $80 \%$ of total assets for the period 1997-2004. They find that average level of XE is 0.5 ; non-state-owned banks were $8 \%$ to $18 \%$ more X-efficient than state-owned banks. Higher levels of XE was positively related to profits and negatively related with non-performing loans. Chen, Skully, and Brown (2005) [9] examined allocative and X-efficiency among 43 Chinese banks during the period 1993-2000. The sample included four SOCBs, seven nation-wide JSCBs, 24 regional JSCBs, and eight international trust and investment trust banks. The authors also present estimates for the three forms of efficiency both before (1993-1994), and after (1996-2000) China's 1995 financial deregulation via the Commercial Bank Law of 1995. Before deregulation, 1993-1994, the average efficiency scores were 0.784 (TE), 0.559 (AE), and 0.465 (TCE). Post deregulation, 1996-1997, the three scores were 0.809, 0.669, and 0.533, respectively. Scores were higher in 1999-2000 than 1993-1994 (for one interpretation is that efficiency increased in the short run under deregulation, but was falling a few years later, the "long run"). Non-state owned banks were more profitable than state-owned banks.

Matthews, and Zhang (2010) [10] examined productivity growth among three types of Chinese banks for the period 1997-2007; State-Owned Commercial Banks (SOCBs); Joint-Stock Banks (JSCBs), and; City Commercial Banks (CCBs). CCBs are often majority or wholly-owned by the government and tied to a local region. Until 1995 the banking system was controlled by the central government. This study thus begins almost immediately after the beginning of the separation of the banking system from the central government. Total Factor Productivity (TFP) growth was estimated separately for 1998-2002, and 2003-2007. The results show that TFP growth by the SOCBs and the JSCBs has on average been zero but productivity growth of the CCBs has been $15 \%$ a year. Among CCBs the main driver of productivity growth was increases in XE. The reform of the Chinese banking system led to increases in productivity is the first sub-period. However, productivity growth in the second sub-period was negative for SOCBs and JSCBs. One interpretation is that productivity growth, which can't continue indefinitely, simply occurred in the first sub-period.

Two articles about the effect of China entering the WTO. Yao, Han, Feng (2008) [11] look at Chinese commercial bank efficiency both before and after China joined the WTO in December 2001. The period of study is 1998-2005. Average X-efficiency for all banks over the entire period was 0.85. China entered the WTO in December 2001. Average XE score from 1998 thru 2001 was 0.82. From 2002-2005 the score was 0.90. The average score increased over the entire period, from 0.86 in 1998 to 0.92 in 2004. Total factor productivity of the entire sample banks increased significantly by $5.6 \%$ per annum over the data period. Of this $5.60 \%$ figure efficiency growth was $2.88 \%$ per year and technical change growth of $2.64 \%$ per year. Efficiency growth measures the extent to which banks approach the frontier, while technological growth measures how fast the frontier is 
shifting out. The majority of productivity growth among state-owned (joint equity) banks was efficiency (technological) growth. And, after China joined the WTO total factor productivity grew at an annual rate of more than $10 \%$. The WTO provided strong incentives for productivity and X-efficiency growth.

Rezvanian, Ariss, and Mehdian (2011) [12] studied the effects of China's admission to the WTO and deregulation of foreign banks in China on XE, technological change, and changes in total factor productivity. The data consists of 62 domestic and foreign banks operating in China over the entire 9-year period between 1998 and 2006. They use the term "pure technical efficiency" which greatly overlaps the characteristics of XE. In 1998, 2001, and $2006 \mathrm{XE}$ for all banks averaged 0.97, 0.96, and 0.98, respectively. XE increased after China entered the WTO. Among foreign, domestic, the "Big 4", and JSCBs the figures for 2001 were $0.96,0.96,1.0$, and 0.97 , respectively. For 2006 the figures were 1.0, 0.98, 1.0, and 0.99, respectively. XE for all four groups increased after China entered the WTO. Using two sub-periods, 1998-2001, and 2002-2006, show that overall technical or X-efficiency for all banks increased by $10.4 \%$ after entrance to the WTO. Technological progress increased by $2.3 \%$, and total factor productivity increased by $12.4 \%$ after WTO admission. Only the Big Four failed to increase any of the three components of efficiency. Overall, entrance to the WTO increased efficiency of Chinese banks.

Next are three articles on "general effects of financial considerations" on XE. Wu, Chen, and Lin (2009) [13] estimated the effects of a bank issuing an IPO on ROA. Their sample is 14 commercial banks including the Big Four for the period 1996-2004. They find that ROA increases from the time the bank issues an IPO through the period immediately following the issuance of the IPO. However, over time the increase in ROA gets smaller.

Luo and Yao (2010) [14] used data from 14 banks listed on a stock exchange to investigate the effects of being listed on bank efficiency. X-efficiency increased from the year before to their IPO year. Second, one year after the IPO X-efficiency either remained constant or fell by a very small amount. Third, X-efficiency among SOBs is below CBs and JEBs by about two percent... the effect of the IPO is to raise X-efficiency by about $4.1 \%$.

Hefferman and $\mathrm{Fu}$ (2010) [15] investigated comparative performance among different types of Chinese banks between 1999 and 2006. The data comes from BankScope, the Almanac of China's Finance and Banking, China Statistical Yearbook and bank websites. Independent variables measuring performance include whether the stock is listed on the stock exchange and the percent of ownership being foreign. Profits, a measure of performance, are measured by value added and the net interest margin. Results suggest that the type of bank affects performance, but the size of the bank does not. Whether the bank's stock is listed on the stock exchange and the percent of foreign ownership show no significant influence on performance. The data suggest that state-owned banks are less X-efficient and have lower profits than joint-stock banks which is consistent with prior results.

Two articles about Hong Kong. Fung, and Cheng (2010) [16] asked whether Hong Kong banks are converging in terms of total factor productivity. The sample is Hong Kong banks that cover all the locally incorporated licensed banks in the territory for the period 1993 to 2002. The authors identify two causes determining productivity and two theories of productivity convergence. The two causes are X-efficiency and scale economies. Their definition of X-efficiency includes both technical and allocative efficiencies. The determination of X-efficiency is management's ability to control costs and/or maximize revenues. The authors cite empirical literature showing that X-efficiency differences are larger than scale economies. The authors find no support for "absolute convergence", that is productivity differences among banks should disappear. The cause of absolute convergence is the domination of scale economies over X-efficiency on productivity levels. Mergers and acquisition affecting scale economies is mentioned as a major cause of scale economies. However, the findings from this study do not support the "absolute convergence" hypothesis as scale economies are shown to have a relatively small affect on costs and productivity. Their findings do support the "conditional convergence" hypothesis. That is, costs and productivity levels and differences are contingent upon the firm's level of X-efficiency.

Kwan (2006) [17] investigated causes of X-(in)efficiency among Hong Kong (HK) banks from 1992-1999. For the period under study X-efficiency among HK banks averaged from 0.7 to 0.85 . Among large banks XE increased from 0.63 to 0.76 , while among small banks the increase was from 0.69 to 0.77 . Small banks, which tended to be privately-owned, were somewhat more X-efficient than large banks which tended to be publically-owned. Not only were large banks more X-inefficient, but their X-inefficiency was more persistent. These results are consistent with both agency theory and XE theory. An interesting result is that whereas XE increased from 1992 thru 1997, the year China gained independence from England, in 1998 and 1999 XE decreased. For all banks it decreased from 0.78 to 0.71 . For large and small banks the decrease was from 0.77 to 0.75 , and from 
0.84 to 0.78 . Small banks, the more privately-owned banks, were more negatively affected by the change-over from a more laissez-faire administration to a communist nation. On the other hand, entrance of Hong Kong into the WTO in 1995 had no noticeable effect on the trend of increasing XE.

\section{Summary and Conclusion}

XE theory predicts that firms perform closer to potential when they face more "pressure". The results of the research presented here verify the predictions. Private-owned banks are more X-efficient than state-owned banks. Deregulation, which increases competition (pressure), increases XE. China's entry into the WTO increased competition from foreign banks and increased XE. When banks issue an IPO, they become subject to market pressures, and XE increases. Empirical evidence on XE covers firms in many industries in every continent of the world and the studies exceed 200. The evidences from all 200+ studies are very consistent with each other and support XE theory [18] [19]. The results from the studies in banking in China and several other Asian countries are also consistent with studies done on banking in many other countries in all parts of the world. The evidence for these other nations is consistent with the overall results for China [20].

\section{References}

[1] Leibenstein, H. (1966) Allocative Efficiency vs. X-Efficiency. American Economic Review, 56, 392-415.

[2] Mundell, R. (1962) Review of L. H. Janssen, Free Trade, Protection and Customs Union. American Economic Review, $\mathbf{5 2}, 622$.

[3] Fu, X. and Hefferman, S. (2009) The Effects of Reform on China's Bank Structure and Performance. Journal of Banking \& Finance, 33, 39-52. http://dx.doi.org/10.1016/j.jbankfin.2006.11.023

[4] Fu, X. and Hefferman, S. (2007) Cost X-Efficiency in China's Banking Sector. China Economic Review, $18,35-53$. http://dx.doi.org/10.1016/j.chieco.2006.10.002

[5] Yao, S, Jiang, C., Feng, G. and Willenbockel, D. (2007) WTO Challenges and Efficiency of Chinese Banks. Applied Economics, 39, 629-643. http://dx.doi.org/10.1080/00036840500447799

[6] Jiang, C., Yao, S. and Zhang, Z. (2009) The Effects of Governance Changes on Bank Efficiency in China: A Stochastic Distance Function Approach. China Economic Review, 20, 717-731. http://dx.doi.org/10.1016/j.chieco.2009.05.005

[7] Fu, X. and Hefferman, S. (2009) The Effects of Reform on China's Bank Structure and Performance. Journal of Banking \& Finance, 33, 39-52. http://dx.doi.org/10.1016/j.jbankfin.2006.11.023

[8] García-Herrero, A., Gavilá, S. and Santabárbara, D. (2009) What Explains the Low Profitability of Chinese Banks? Journal of Banking \& Finance, 33, 2080-2092. http://dx.doi.org/10.1016/j.jbankfin.2009.05.005

[9] Chen, X., Skully, M. and Brown, K (2005) Banking Efficiency in China: Application of DEA to Pre- and Post-Deregulation Eras: 1993-2000. China Economic Review, 16, 229-245. http://dx.doi.org/10.1016/i.chieco.2005.02.001

[10] Matthews, K. and Zhang, N. (2010) Bank Productivity in China 1997-2007: Measurement and Convergence. China Economic Review, 21, 617-628. http://dx.doi.org/10.1016/j.chieco.2010.06.004

[11] Yao, S., Han, Z. and Feng, G. (2008) Ownership Reform, Foreign Competition and Efficiency of Chinese Commercial Banks: A Non-Parametric Approach. World Economy, 31, 1310-1326. http://dx.doi.org/10.1111/j.1467-9701.2008.01130.x

[12] Rezvanian, R., Ariss, R. and Mehdian, S. (2011) Cost Efficiency, Technological Progress and Productivity Growth of Chinese Banking Pre- and Post-WTO Accession. Applied Financial Economics, 21, 437-454. http://dx.doi.org/10.1080/09603107.2010.532110

[13] Wu, H., Chen, C. and Lin, H. (2009) Can a Stock Market Listing Help to Improve the Operational Performance. Journal of Economic Policy Reform, 12, 13-28. http://dx.doi.org/10.1080/17487870802677742

[14] Luo, D. and Yao, S. (2010) World Financial Crises and the Rise of Chinese Commercial Banks: An Efficiency Analysis Using DEA. Applied Financial Economics, 20, 1515-1530. http://dx.doi.org/10.1080/09603107.2010.508717

[15] Heffernan, S. and Fu, X. (2010) Determinants of Financial Performance in Chinese Banking. Applied Financial Economics, 20, 1585-1600. http://dx.doi.org/10.1080/09603107.2010.505553

[16] Fung, M. and Cheng, A. (2010) Convergence of Total Factor Productivity among Banks: Hong Kong's Experience. Global Finance Journal, 21, 201-210. http://dx.doi.org/10.1016/j.gfj.2010.06.006

[17] Kwan, S. (2006) The X-Efficiency of Commercial Banks in Hong Kong. Journal of Banking \& Finance, 30, $1127-$ 1147. http://dx.doi.org/10.1016/j.jbankfin.2005.05.016 
[18] Frantz, R. (1997) X-Efficiency: Theory, Evidence, and Applications. 2nd Edition, Kluwer, Norwell. http://dx.doi.org/10.1007/978-1-4615-6265-8

[19] Frantz, R. (2007) Empirical Evidence on X-Efficiency, 1967-2004. In: Frantz, R., Ed., Renaissance in Behavioral Economics: Essays in Honor of Harvey Leibenstein, Routledge, New York, 211-227.

[20] Frantz, R. (2015) X-Efficiency and Regulation. Antitrust Bulletin, in Press. 